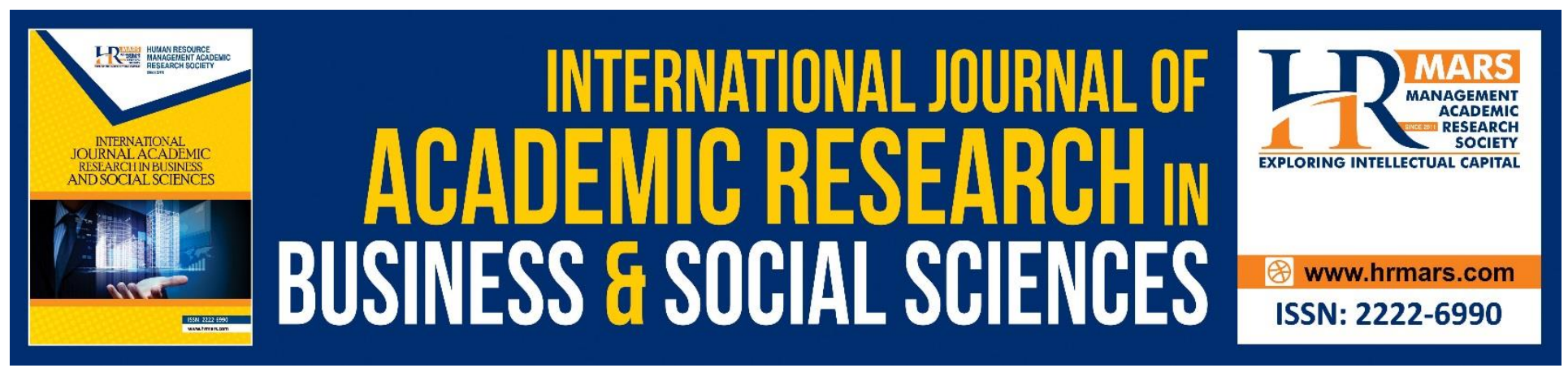

\title{
Is it True if Website Quality have Impact For Your Online Purchase Intention?
}

Bagja Waluya, Dewi Pancawati Novalita, Ratna Dewi Cahyati

To Link this Article: http://dx.doi.org/10.6007/IJARBSS/v9-i3/5743 DOI: $10.6007 /$ IJARBSS/v9-i3/5743

Received: 21 Jan 2019, Revised: 19 Feb 2019, Accepted: 08 March 2019

Published Online: 28 March 2019

In-Text Citation: (Waluya, Novalita, \& Cahyati, 2019)

To Cite this Article: Waluya, B., Novalita, D. P., \& Cahyati, R. D. (2019). Is it True if Website Quality have Impact For Your Online Purchase Intention? International Journal of Academic Research in Business and Social Sciences, 9(3), 774-781.

\section{Copyright: (C) 2019 The Author(s)}

Published by Human Resource Management Academic Research Society (www.hrmars.com)

This article is published under the Creative Commons Attribution (CC BY 4.0) license. Anyone may reproduce, distribute, translate and create derivative works of this article (for both commercial and non-commercial purposes), subject to full attribution to the original publication and authors. The full terms of this license may be seen

at: http://creativecommons.org/licences/by/4.0/legalcode

Vol. 9, No. 3, 2019, Pg. 774 - 781

http://hrmars.com/index.php/pages/detail/IJARBSS

JOURNAL HOMEPAGE

Full Terms \& Conditions of access and use can be found at http://hrmars.com/index.php/pages/detail/publication-ethics 


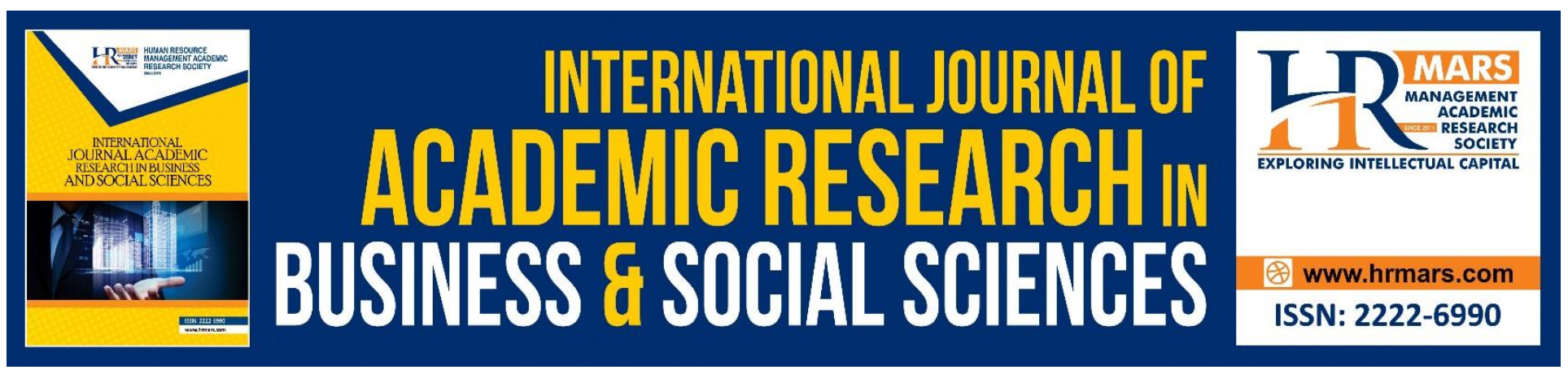

\title{
Is it True if Website Quality have Impact For Your Online Purchase Intention?
}

\author{
Bagja Waluya, Dewi Pancawati Novalita, Ratna Dewi Cahyati \\ Universitas Pendidikan Indonesia, Indonesia
}

\begin{abstract}
Website is part of online marketing media that have a big role in helping promote hotel product and services. The Trans Luxury Hotel Bandung presently faced with marketing problem that had impact to decreasing the intention of guests to make reservations through the hotel official website. The Effort made to increase online purchase intention at The Trans Luxury Hotel Bandung is by improving the hotel website quality that consisting of hotel website usability, hotel website functionality and hotel website security and privacy. The type of this research is descriptive and verificative research with explanatory survey method. The purpose of the study is to determine the effect of website quality to online purchase intention at The Trans Luxury Hotel Bandung. The number respondent are 115 guests who has stayed and accessed website www.thetranshotel.com. The data analysis technique used is multiple regression analysis technique. The result showed that website quality has an influence toward online purchase intention at The Trans Luxury Hotel Bandung.
\end{abstract}

Keywords: Website Quality, Online Purchase Intention

\section{INTRODUCTION}

Bandung is the province capital of the West Java with the development of tourism that continues to increase. Because of its tourism industry potential, it is not surprising that Bandung has become a tourist destination for domestic and foreign tourists. The high mobility level of tourist must be supported by completely and quality tourism facilities. To meet these needs, the existence of hotel becomes one of the important supporting facilities and can even be referred as the main instrument of tourism, so that the tourists who come or visit Bandung will be fulfilled on accommodation. Many Hotel in Bandung develop their website to increase their occupancy.

Ali (2016: 215) in his research journal suggested that nowadays website is an integral part of the hotel which can provide information about the hotel entire product and service, this activity is conceded out because it has the possibility to increase consumer purchase interest. . Previous research revealed that the positive influence of website quality can influence consumers to make purchases (Wang et al., 2015: 108).

The five star hotels are classified as the most luxurious hotel among its class. All the facilities are also required to be fully equipped according to the specified standards and have the best service quality. 
The Trans Luxury Hotel Bandung is one of the five-star luxury hotels that located in the city of Bandung. The number of guests who make reservations online through the official website hotel at www.thetranshotel.com is lower than the number of guests who make reservations through online travel agents. The low intention of guests to make reservations through the hotel website causes losses to the hotel, where to create and maintain a website requires budget and low reservations through the website is not comparative to the amount of costs that incurred to create and maintain a website. Therefore, this problem must be followed up immediately to reduce the impact that triggers to the room occupancy level.In early 2018 The Trans Luxury Hotel Bandung was upgraded and improved the quality of their official website to be more effective and efficient, managed directly by the hotel management so that it can be updated and controlled periodically with the domain www.thetranshotel.com which is expected to be able to increase the guest intention to make reservations online via hotel website. Online purchase intention is defined as the willingness and desire of consumers to make online transactions after reviewing the quality and information of the website (Ali, 2016: 215).In order to increase the guests intention to make reservations through the hotel website, The Trans Luxury Hotel Bandung starts implementing an online marketing strategy that focuses on website quality. Previous research revealed that affirmative website quality can influence consumers to make purchases (Wang et al., 2015: 108). There are various dimensions to measure website quality, one of them is the dimension by Wang et al., (2015: 108) on Ali (2016: 215) which consists of the hotel usability website, hotel website functionality and hotel website security and privacy. Ali (2016: 215) in his research journal suggested that nowadays website is an integral part of the hotel which can provide information about the hotel entire product and service, this activity is conceded out because it has the possibility to increase consumer purchase interest.

The purpose of this study are as follow. The objective of the study are as follow:

i. To find out the guest response to the website quality at The Trans Luxury Hotel Bandung.

ii. To find out the guest response to the online purchase intention at The Trans Luxury Hotel Bandung.

iii. To find out whether or not the influence of the website quality on online purchase intention at The Trans Luxury Hotel Bandung

\section{METHODOLOGY}

This research examines the website quality and its influence to online purchasing intention at The Trans Luxury Hotel Bandung. As for the independent variable, the website quality consists of three indicators, there are the hotel usability website, hotel website functionality and hotel website security and privacy. While the dependent variable namely online purchase intention consists of two indicators, willingness to purchase and willingness to trust website. Respondents from this study were individual guests staying and accessing the official website of The Trans Luxury Hotel Bandung, www.thetranshotel.com. This research was conducted in less than one year, therefore the research method used was cross sectional study. Respondents from this study were individual guests staying and accessing the official website of The Trans Luxury Hotel Bandung, www.thetranshotel.com. This research was conducted in less than one year, therefore the research method used was cross sectional study. 
The population of this study were individual guests who stayed at The Trans Luxury Hotel Bandung and had accessed the website www.thetranshotel.com totaling 19,846 guests. This study uses a sample of 115 respondents which is calculated using the Tabachnick and Fidell (2013: 123) formula. The technique sampling used in this study is a systematic random sampling. Based on the data sources listed, the types of data collected in this study are primary and secondary data. Data collection techniques used in this study are interviews, observations, questionnaires and literature studies.

\section{RESULTS}

Table 1 provides respondents Response to Hotel Website Usability on thetranshotel.com website. There is $s$ any five alternatives to answer of the statement : Strongly Dissagree (1), Dissagree (2), Slightlty Agree (3), Agree (4), Strongly Agree (5)

TABLE 1: Percentage frequency Response about usability of the Trans Luxury Hotel website quality

\begin{tabular}{|c|c|c|c|c|c|c|}
\hline \multicolumn{7}{|l|}{ Hotel Website Security and Privacy } \\
\hline \multirow{3}{*}{ Statement } & \multicolumn{5}{|c|}{ Alternative Answers } & \multirow{3}{*}{$\pi \%$} \\
\hline & 1 & 2 & 3 & 4 & 5 & \\
\hline & $\%$ & $\%$ & $\%$ & $\%$ & $\%$ & \\
\hline $\begin{array}{l}\text { I strongly believe in the security of my personal confidential data } \\
\text { and other guests on the hotel website }\end{array}$ & 0 & $\begin{array}{l}2, \\
6\end{array}$ & $\begin{array}{c}17 \\
4\end{array}$ & $\begin{array}{l}4 \\
0\end{array}$ & $\begin{array}{l}4 \\
0\end{array}$ & 33,61 \\
\hline $\begin{array}{l}\text { I strongly believe in information about the security of the online } \\
\text { payment system on the hotel website }\end{array}$ & $\begin{array}{l}0 \\
9\end{array}$ & $\begin{array}{l}1 \\
7\end{array}$ & $\begin{array}{c}15 \\
7\end{array}$ & $\begin{array}{l}4 \\
4, \\
3\end{array}$ & $\begin{array}{l}3 \\
7, \\
4\end{array}$ & 33,47 \\
\hline $\begin{array}{l}\text { I strongly believe in the security information of hotel websites that } \\
\text { have been certified by Terremark Cybertrust Security }\end{array}$ & $\begin{array}{l}1 \\
7\end{array}$ & $\begin{array}{l}0, \\
9\end{array}$ & $\begin{array}{c}17 \\
4\end{array}$ & $\begin{array}{l}4 \\
7\end{array}$ & $\begin{array}{l}3 \\
3\end{array}$ & 32,92 \\
\hline
\end{tabular}


INTERNATIONAL JOURNAL OF ACADEMIC RESEARCH IN BUSINESS AND SOCIAL SCIENCES

Vol. 9, No. 3, March, 2019, E-ISSN: 222 2-6990 ¿ 2019 HRMARS

TABLE 2: Percentage frequency Response about functionality of the Trans Luxury Hotel website quality

\begin{tabular}{|c|c|c|c|c|c|c|}
\hline \multirow{3}{*}{ Statement } & \multicolumn{5}{|c|}{ Alternative Answers } & \multirow{3}{*}{$\pi \%$} \\
\hline & \multirow{2}{*}{$\begin{array}{ll}1 \\
\end{array}$} & \multirow{2}{*}{$\begin{array}{l}2 \\
\%\end{array}$} & \multirow{2}{*}{$\begin{array}{l}3 \\
\%\end{array}$} & \multirow{2}{*}{$\begin{array}{l}4 \\
\%\end{array}$} & \multirow{2}{*}{$\begin{array}{l}5 \\
\end{array}$} & \\
\hline & & & & & & \\
\hline The language used on the hotel website is very clear & 0 & 0 & $\begin{array}{l}14, \\
8\end{array}$ & $\begin{array}{l}49, \\
6\end{array}$ & $\begin{array}{l}35 \\
7\end{array}$ & $\begin{array}{l}17,0 \\
8\end{array}$ \\
\hline $\begin{array}{l}\text { The information contained on the hotel website is very easy to } \\
\text { understand }\end{array}$ & 0 & $\begin{array}{l}2, \\
6\end{array}$ & $\begin{array}{l}15, \\
7\end{array}$ & $\begin{array}{l}47 \\
8\end{array}$ & $\begin{array}{l}33, \\
9\end{array}$ & $\begin{array}{l}16,7 \\
6\end{array}$ \\
\hline $\begin{array}{l}\text { The design and background display on the hotel website is very } \\
\text { practical }\end{array}$ & $\begin{array}{l}0, \\
9\end{array}$ & $\begin{array}{l}2, \\
6\end{array}$ & $\begin{array}{l}13, \\
9\end{array}$ & $\begin{array}{l}45, \\
2\end{array}$ & $\begin{array}{l}37, \\
4\end{array}$ & $\begin{array}{l}16,8 \\
7\end{array}$ \\
\hline $\begin{array}{l}\text { The arrangement of information on the hotel website is very good } \\
\text { and neat }\end{array}$ & $\begin{array}{l}0, \\
9\end{array}$ & $\begin{array}{l}1, \\
7\end{array}$ & $\begin{array}{l}17, \\
4\end{array}$ & $\begin{array}{l}50, \\
4\end{array}$ & $\begin{array}{l}29, \\
6\end{array}$ & $\begin{array}{l}16,4 \\
8\end{array}$ \\
\hline $\begin{array}{l}\text { The graphic and text display on the hotel website is very } \\
\text { appropriate }\end{array}$ & $\begin{array}{l}2, \\
6\end{array}$ & $\begin{array}{l}1 \\
7\end{array}$ & 20 & $\begin{array}{l}44, \\
3\end{array}$ & $\begin{array}{l}31, \\
3 \\
\end{array}$ & $\begin{array}{l}16,2 \\
3\end{array}$ \\
\hline Navigation on the hotel website is very easy to use & $\begin{array}{l}0, \\
9\end{array}$ & $\begin{array}{l}1, \\
7\end{array}$ & $\begin{array}{l}18, \\
3\end{array}$ & $\begin{array}{l}46, \\
1\end{array}$ & 33 & $\begin{array}{l}16,5 \\
8\end{array}$ \\
\hline
\end{tabular}

TABLE 3: Percentage frequency Response about Security and Privacy of the Trans Luxury Hotel website quality

\begin{tabular}{|c|c|c|c|c|c|c|}
\hline \multirow{3}{*}{ Statement } & \multicolumn{5}{|c|}{ Alternative Answers } & \multirow{3}{*}{$\pi \%$} \\
\hline & 1 & 2 & 3 & 4 & 5 & \\
\hline & $\%$ & $\%$ & $\%$ & $\%$ & $\%$ & \\
\hline $\begin{array}{l}\text { Information about the reservation process on the hotel website } \\
\text { is very complete }\end{array}$ & 0 & $\begin{array}{l}1, \\
7\end{array}$ & $\begin{array}{l}18, \\
3\end{array}$ & $\begin{array}{l}4 \\
7\end{array}$ & $\begin{array}{l}3 \\
3\end{array}$ & $\begin{array}{l}20 \\
.4 \\
5\end{array}$ \\
\hline $\begin{array}{l}\text { Information on hotel facilities on the hotel website is very } \\
\text { complete }\end{array}$ & 0 & $\begin{array}{l}2, \\
6\end{array}$ & $\begin{array}{l}19, \\
1\end{array}$ & $\begin{array}{l}3 \\
4, \\
8\end{array}$ & $\begin{array}{l}4 \\
3, \\
5\end{array}$ & 20,84 \\
\hline $\begin{array}{l}\text { Information about promotions and special offers on the hotel } \\
\text { website is very complete }\end{array}$ & $\begin{array}{l}1, \\
7\end{array}$ & $\begin{array}{l}2, \\
6\end{array}$ & $\begin{array}{l}24, \\
3\end{array}$ & $\begin{array}{l}4 \\
5 \\
2 \\
\end{array}$ & $\begin{array}{l}2 \\
6, \\
1 \\
\end{array}$ & 19,46 \\
\hline $\begin{array}{l}\text { Information about the price of each room on the hotel website } \\
\text { is very complete }\end{array}$ & $\begin{array}{l}1, \\
7\end{array}$ & $\begin{array}{l}0, \\
9\end{array}$ & $\begin{array}{l}23, \\
5\end{array}$ & $\begin{array}{l}4 \\
0\end{array}$ & $\begin{array}{l}3 \\
3, \\
9\end{array}$ & 20,06 \\
\hline
\end{tabular}


INTERNATIONAL JOURNAL OF ACADEMIC RESEARCH IN BUSINESS AND SOCIAL SCIENCES

Vol. 9, No. 3, March, 2019, E-ISSN: 222 2-6990 @ 2019 HRMARS

TABLE 4: Percentage frequency Response about Online Purchase Intention to The Trans Luxury Hotel

\begin{tabular}{|c|c|c|c|c|c|c|}
\hline \multicolumn{7}{|l|}{ Willingness to Purchase } \\
\hline \multirow{3}{*}{ Statement } & \multicolumn{5}{|c|}{ Alternative Answers } & \multirow{3}{*}{$\%$} \\
\hline & 1 & 2 & 3 & 4 & 5 & \\
\hline & $\%$ & $\%$ & $\%$ & $\%$ & $\%$ & \\
\hline $\begin{array}{l}\text { I strongly believe in making purchases through the hotel } \\
\text { website in the future. }\end{array}$ & $\begin{array}{l}2, \\
6\end{array}$ & $\begin{array}{l}1, \\
7\end{array}$ & $\begin{array}{c}15 \\
7\end{array}$ & $\begin{array}{c}41 \\
7\end{array}$ & $\begin{array}{c}38, \\
3\end{array}$ & $\begin{array}{c}100 \\
\%\end{array}$ \\
\hline \multicolumn{7}{|c|}{ Willingness to Trust of Website } \\
\hline $\begin{array}{l}\text { I strongly believe in the information contained in the hotel } \\
\text { website. }\end{array}$ & $\begin{array}{l}0 \\
9\end{array}$ & $\begin{array}{l}1 \\
7\end{array}$ & $\begin{array}{c}13, \\
9\end{array}$ & $\begin{array}{c}48 \\
7\end{array}$ & $\begin{array}{c}34 \\
8\end{array}$ & $\begin{array}{l}50,4 \\
2\end{array}$ \\
\hline I feel confident to use the hotel website in the future & $\begin{array}{l}2, \\
6\end{array}$ & $\begin{array}{l}0, \\
9\end{array}$ & $\begin{array}{c}17 \\
4\end{array}$ & $\begin{array}{c}44 \\
3\end{array}$ & $\begin{array}{c}34 \\
8\end{array}$ & $\begin{array}{l}49,5 \\
8\end{array}$ \\
\hline
\end{tabular}

\section{DISCUSSION}

Based on the results of research from the distribution questionnaires to guests who stay and access the website of The Trans Luxury Hotel Bandung as many as 115 respondents, it is known that the quality website at The Trans Luxury Hotel Bandung gets a total score of 6,575 which are classified as high and located at intervals of 1,160 -8,120. The best response from respondents is dimensions the hotel security and privacy website with an average score of 476 with a percentage of $33.74 \%$. In this case, website www.thetranshotel.com has provided the best quality in terms of security and trust in websites that have been certified by the Terremark Cybertrust Security system. Strengthening the statement from Wang et.al (2015: 113) that hotel website security and privacy is one of the important factors that can influence consumer purchasing decisions through the website. Dimensions with the lowest average score is hotel website functionality with a total of 462.6 and a percentage of $32.79 \%$. This shows that the information feature of the hotel website The Trans Luxury Hotel Bandung has not provided a functional experience to guests and the information available is still considered unsatisfactory.

The result from this research shows that online purchase intention at The Trans Luxury Hotel Bandung reached a score of 1,419 which is high and located in the interval $345-1,725$. In this variable, the two dimensions of willingness to purchase and willingness to trust website have the same response - with the same average score and equal percentage of $50 \%$. This shows that each dimension has an attachment to each other that encourages the trust of users or guests to choose to make transactions with The Trans Luxury Hotel Bandung through the website www.thetranshotel.com. Strengthening Ali's statement (2016: 217) that online purchase intentions occur due to consumer confidence regarding the quality and information presented on the website that affect the willingness of consumers to conduct transactions through the hotel website. 


\section{CONCLUSION}

The result of the hypothesis obtained about the effect of website quality on online purchase intention at The Trans Luxury Hotel Bandung simultaneously has a total effect of 0.581 or $58.1 \%$ of online purchase intention variables, while the remaining $41.9 \%$ is contributed by other factors not examined in this study. Partially, hotel website security and privacy variables have a significant influence on online purchase intention, while the hotel usability website and hotel website functionality do not have a significant influence. This research has contribute specially for the object and hotel industries. Therefore, the Trans Luxury Hotel Bandung should pay attention to and review any detailed information related to the hotel as well as update or update every latest information periodically so as to facilitate guests in finding information needed on The Trans Luxury Hotel Bandung. Even better if the Trans Luxury Hotel Bandung can add a feedback menu such as web feedback, hotel review and customer service direct contact in order to improve the website quality that matches the expectations of guests. The hotel is more often to continue communicating the convenience and benefits that guests get if making reservations through the hotel website and adding more reward to guests who make reservations through the website

\section{REFERENCES}

1. Abou-Shouk, M. A., \& Khalifa, G. S. (2017). The influence of website quality dimensions on epurchasing behaviour and e-loyalty: a comparative study of Egyptian travel agents and hotels. Journal of Travel \& Tourism Marketing, 34(5), 608-623.

2. Ali, F. (2016). Hotel website quality, perceived flow, customer satisfaction and purchase intention. Journal of Hospitality and Tourism Technology, 7(2), 213-228.

3. Amaro, S., \& Duarte, P. (2015). An integrative model of consumers' intentions to purchase travel online. Tourism management, 46, 64-79.

4. Au Yeung, T., Law, R., 2004. Extending the modified heuristic usability evaluationtechnique to chain and independent hotel websites. IJHM 23 (3), 307-313.

5. Bai, B., Law, R., \& Wen, I. (2008). The impact of website quality on customer satisfaction and purchase intentions: Evidence from Chinese online visitors. International journal of hospitality management, 27(3), 391-402.

6. Buhalis, D., \& Law, R. (2008). Progress in information technology and tourism management: 20 years on and 10 years after the Internet-The state of eTourism research. Tourism management, 29(4), 609-623.

7. Chang, H.C., Chen, S.W., 2008. The impact of online store environment cues on pur-chase intention: trust and perceived risk as a mediator. Online Inf. Rev. 32 (6), 818-841.

8. Fidell, S., Tabachnick, B., Mestre, V., \& Fidell, L. (2013). Aircraft noise-induced awakenings are more reasonably predicted from relative than from absolute sound exposure levels. The Journal of the Acoustical Society of America, 134(5), 3645-3653.

9. Ha, H. Y., \& Janda, S. (2014). The effect of customized information on online purchase intentions. Internet Research, 24(4), 496-519.

10. Hsu, C. L., Chang, K. C., \& Chen, M. C. (2012). The impact of website quality on customer satisfaction and purchase intention: perceived playfulness and perceived flow as mediators. Information Systems and e-Business Management, 10(4), 549-570. 
11. Jeong, M., Oh, H., Gregoire, M., 2003. Conceptualizing web site quality and its con-sequences in the lodging industry. IJHM 22 (2), 161-175.

12. Kim, W. G., \& Kim, D. J. (2004). Factors affecting online hotel reservation intention between online and non-online customers. International Journal of Hospitality Management, 23(4), 381-395.

13. Leung, D., Law, R., \& Lee, H. A. (2016). A modified model for hotel website functionality evaluation. Journal of Travel \& Tourism Marketing, 33(9), 1268-1285.

14. Ponte, E. B., Carvajal-Trujillo, E., \& Escobar-Rodríguez, T. (2015). Influence of trust and perceived value on the intention to purchase travel online: Integrating the effects of assurance on trust antecedents. Tourism Management, 47, 286-302.

15. Saw, S. L., Goh, Y. N., \& Isa, S. M. (2015). Exploring consumers' intention toward online hotel reservations: insights from Malaysia. Problems and Perspectives in Management, 13(2), 249257.

16. Sekaran, U., \& Bougie, R. (2010). Theoretical framework in theoretical framework and hypothesis development. Research methods for business: A skill building approach, 80.

17. Sekaran, U. (2014). Metodologi Penelitian untuk bisnis (Research Methods For Business). Buku 1 Edisi 4. Jakarta:Salemba Empat.

18. Silalahi, U. (2012). Metode Penelitian Sosial. Bandung: Refika Aditama

19. Sugiyono. (2014) Metode Penelitian Kuantitatif Kualitatif dan R\&D. Bandung : Alfabeta

20. Sujarweni, V. W. (2014). Metodologi Penelitian. Yogyakarta: Pustaka Baru.

21. Wang, L., Law, R., Guillet, B. D., Hung, K., \& Fong, D. K. C. (2015). Impact of hotel website quality on online booking intentions: eTrust as a mediator. International Journal of Hospitality Management, 47, 108-115.

22. Wirawan, W. (2013). Peningkatan Niat Pembelian melalui Website. The Winners, 14(1), 4854.

23. Xiang, Z., Wang, D., O'Leary, J. T., \& Fesenmaier, D. R. (2015). Adapting to the internet: trends in travelers' use of the web for trip planning. Journal of Travel Research, 54(4), 511-527. 